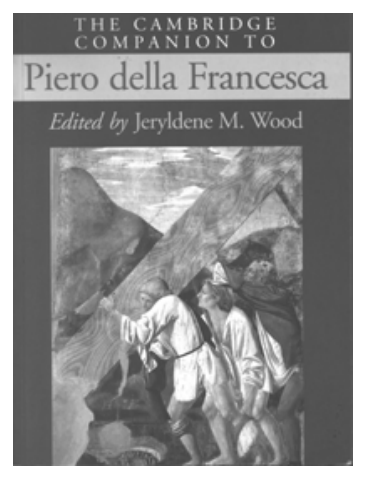

Jeryldene M. Wood, ed.

\title{
The Cambridge Companion to Piero della Francesca
}

Cambridge: Cambridge University Press, 2002

Reviewed by João Pedro Xavier

The Cambridge Companion to Piero della Francesca, edited by Jeryldene M. Wood, is an excellent guide to the work of this great painter and mathematician of the Renaissance.

It is conceived as a collection of essays from authors from several fields. The contributors are: Diane Cole Ahl ("The Misericordia Polyptych: Reflections on Spiritual and Visual Culture in Sansepolcro"); Timothy Verdon ("The Spiritual Worls of Piero's Art"); Jeryldene M. Wood ("Piero's Legend of the True Cross and the Friars of San Francesco"); Marilyn Aronberg Lavin ("Piero's Meditation on the Nativity"); Jane Bridgeman ("Troppo belli e troppo eccelenti: Observations on Dress in the Work of Piero della Francesca"); Joanna Woods-Marsden ("Piero della Francesca's Ruler Portraits"); Philip Jacks ("The Renaissance Prospettiva: Perspectives of the Ideal City"); Margaret Daly Davis ("Piero's Treatises: The Mathematics of Form”); J.V. Field ("Piero della Francesca's Mathematics"); Anne B. Barriault ("Piero's Parnassus of Modern Painters and Poets").

As the editor explains in the Introduction, the first four essays

explore Piero's religious paintings. Diane Cole Ahl's study of Piero's Misericordia Altarpiece delves into the complex religious, civic, and cultural life of Sansepolcro, providing fresh information about the mission of the confraternity that ordered it and identifying possible painted and sculptural models for Piero's pictures. Timothy Verdon brings theological as well art-historical expertise to his investigation of Piero in terms of their iconography and formal composition but also with respect to their possible reception by lay, confraternal, and monastic patrons". Jeryldene M. Wood own essay studies "the Legend of the True Cross at Arezzo and, like Ahl's contribution, investigates the local circumstances underlying a commission; in this instance, the possible motivations of the fifteenth-century Franciscan friars whose church the frescoes still adorn. Marilyn Aronberg Lavin's essay, first published in 1955, is a close reading of a single painting by Piero, the Adoration of the Child, where the artist's "paradoxical" transformation of humble nature into exalted spiritual ideas is analyzed. Jane Bridgeman, a historian of dress, then suggests a different way to approach the chronological and iconographical problems in Piero's oeuvre by correcting several misconceptions and offering new observations about the clothing worn by the characters in his pictures. The subsequent essays by Joanna Woods-Marsden and Philip Jacks take readers to the North Italian courts. Woods-Marsden's discussion of Piero's portraits of Sigismondo Malatesta, Federigo da Montefeltro, and Battista Sforza addresses issues of identity, self-promotion, and gender within Quattrocento ideological structures of power by clarifying the notion of a "true likeness" in the emerging genre of court portraiture. Jacks reviews the thorny problems of attribution and function associated with three paintings of "Ideal Cities", thought to have been ordered for the Urbino court, and connects this type of imagery with contemporary architectural theory and intarsia design. Complementary essays if Piero's mathematical treatises by Margaret Daly Davis and J.V. Field demonstrate the distinctive approaches of scholars in diverse disciplines. Davis, an art historian, analyzes the "interrelatedness" of 
Piero's three treatises, details their reception by other fifteenth- and sixteenth-century art theorists, and underscores their importance to architects and designers of intarsia. Field, from a starting point in the history of mathematics and optics, dissects the particular kinds of problems posed in the treatises to explain Piero's place in the development of Renaissance mathematics and to explore the affinities between is mathematic and artistic practices. The final essay, by Anne Barriault, contemplates the rediscovery of Piero's paintings as sources of inspiration for the art historians Bernard Berenson and Kenneth Clark, the painters Romare Bearden, David Hockney, and William Bailey, the poets Charles Wright, Gjertrud Schnackberg, and Jorie Graham, and the novelist Michael Ondaatje. For these modern writers and painters, Piero's subtle imagination and quiet lyricism resonate across barriers of time and space, thereby enabling the past continually to edify the present".

For the Nexus Network Journal reader we have to point, especially, to the essays of Jacks, Davis and Field as their subject deals, implicitly, with architecture and mathematics, with perspective as the key for the relationship between these two disciplines.

Perspective is the representational system of the three panels analyzed in Philip Jacks's essay, used to visualize the project of the ideal city whose components Alberti had laid out in De re aedificatoria. Thanks to that, this "mental construction" wins a face, with a enormous persuasive value, and these panels, mainly the one in Urbino, act as "demonstration pieces", contributing to the belief that the ideal plan of the perfect city_perhaps a rendering of the Heavenly Jerusalem dreamed of by Federigo da Montefeltro-can become real. Among such components, we find the main protagonists - the buildings and the space they define-and soon we discover that central perspective is the most suitable tool for envisioning a global project for a centralized space, with man in the centre, as we recognize that the masses that shapes space are the regular bodies already treated in the Trattato d'abaco, developed in the Libellus de quinque corporibus regularibus and put into perspective in the De prospectiva pingendi, as Margaret Daly Davis and J.V. Field point out.

In my opinion Davis's remark concerning the importance of practical perspective in the ambience of abacus schools is very significant, as it testifies to the relationship of distance measurement procedures, controlled by sight, with the development of this matter as a representational system and, as shown by J.V. Field, provides its mathematical background, as it is the way to prove the exactness of perspective (De prospectiva pingendi, I.13). The key is, obviously, proportion, expressed mathematically in the form of the famous theorem attributed to Thales de Mileto which can be drawn geometrically as an homothetic transformation, and corresponds arithmetically to the "rule of three" (regola delle tre), extensively treated in the Trattato d'abaco, which was considered by Baxandall (quoted by Davis) as "the universal arithmetical tool of literate Italian commercial people in the Renaissance". Anyway, as Field notes, this is not enough to bring perspective into its projective nature, in spite of being a remarkable achievement for fifteenth-century standards. For this author it is exactly the absence of the notion of infinity, inherent to perspective, that does not permit the recognition of space as an independent entity during Renaissance. The Aristotelian assumption that "space is extension, measured by body" confirms these boundaries. The boundaries would not be broken until the first half of the seventeenth century with the work of Blaise Pascal, which came after the definition of infinite space in the geometry of Desargues. Only since that time has geometry actually became "the science of space" - the immensurable large or infinite space-although philosophers were discussing the infinite a long time before.

170 JoÃo Pedro XAVIER - Review of Wood, ed., The Cambridge Companion Guide to Piero della Francesca 


\section{About the reviewer}

João Pedro Xavier received his degree in Architecture from the Faculty of Architecture of the University of Porto (FAUP) and is licensed as an architect at the College of Architects in Porto since 1986. He won the prizes "Prémio Florêncio de Carvalho" and "Prémio Engo António de Almeida" for scholarship.

He worked in Álvaro Siza's office from 1986 to 1999. At the same time he set up his own practice as an architect. He has participated in several exhibitions, courses and seminars. One of his latest projects was the Exhibition "Matemática Viva" (an interactive exhibition on mathematics), at the Pavilhão do Conhecimento in Lisbon, organized by the Association ATRACTOR, for which also he conceived all the modules on perspective.

He has been teaching geometry since 1985 at Architecture School of Cooperativa Árvore in Porto, Fine Arts School of Porto, and at FAUP from 1991 on. At 1996 he wrote Perspectiva, perspectiva acelerada e contraperspectiva, published by FAUP Publicações at 1997, and became assistant lecturer of that Chair. Has completed his Phd on the same subject, under the advisement of Prof. Arch. Alexandre Alves Costa.

Xavier has always been interested in the relationship between architecture and mathematics, especially geometry. He published several works and papers on the subject, given conferences and lectures and taught courses to high school teachers. He also collaborated with the Ministry of Education, coordinating the team in charge of the elaboration of Descriptive Geometry curricula in Portugal. 